\title{
Analysis of Changes in Serum Levels and Gene Expression Profiles of Novel Adipocytokines (Omentin, Vaspin, Irisin and Visfatin) and Their Correlation with Serum C-reactive Protein Levels in Women Diagnosed with Endometriosis
}

\author{
Endometriozis Tanısı Alan Kadınlarda Yeni Adipositokinlerin (Omentin, \\ Vaspin, İrisin ve Visfatin) Serum Seviyelerindeki ve Gen Ekspresyon \\ Profillerindeki Değişimlerinin Analizi ve Bu Adipositokinlerin Serum \\ C-reaktif Protein Düzeyleri ile Korelasyonu
}

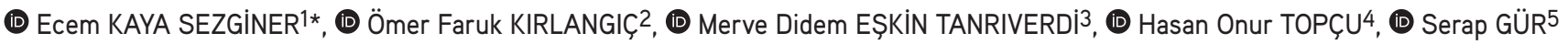

1Ankara University Faculty of Pharmacy, Department of Biochemistry, Ankara, Turkey

2University of Health Sciences Turkey, Gülhane Faculty of Medicine, Department of Medical Biochemistry, Ankara, Turkey

3University of Health Sciences Turkey, Ankara City Hospital, Department of Obstetrics and Gynecology, Ankara, Turkey

${ }^{4}$ Memorial Ankara Hospital, Department of Obstetrics and Gynecology, Ankara, Turkey

${ }^{5}$ Ankara University Faculty of Pharmacy, Department of Pharmacology, Ankara, Turkey

\section{ABSTRACT}

Objectives: This study aimed to investigate the role of new adipocytokines (omentin, vaspin, irisin and visfatin) in the development of endometriosis and the relationship of these adipocytokines with the inflammatory marker, C-reactive protein (CRP) levels in serum.

Materials and Methods: In this study, endometriosis $(n=16)$ and control groups $(n=14)$ were determined via ultrasound. Serum omentin, vaspin and irisin levels were measured by ELISA method. CRP levels in serum and the gene expression of visfatin and vaspin in whole blood samples were determined by clinical analyzer and the real-time polymerase chain reaction, respectively.

Results: Serum irisin and CRP levels in the endometriosis group were significantly higher than in the control group. Irisin protein levels demonstrated a positive correlation with body mass index and CRP in women diagnosed with endometriosis. No statistically significant difference was found in serum omentin and vaspin levels between groups. The visfatin and vaspin gene expression in whole blood samples from the endometriosis group was found to be significantly lower than the control group.

Conclusion: Increased levels of serum irisin and decreased visfatin and vaspin gene expressions in blood may be considered as a potential biomarker in endometriosis. The identification of new adipocytokines, which demonstrate an alteration in the presence of endometriosis and the relationship between these adipocytokines and inflammation will facilitate the detection of mechanisms involved in endometriosis and will lead to the development of targeted therapy.

Key words: Endometriosis, adipocytokines, inflammation

ÖZ

Amaç: Bu çalışmanın amacı, yeni adipositokinlerin (omentin, vaspin, irisin ve visfatin) endometriozis gelişimindeki rolünü ve bu adipositokinlerin inflamatuvar belirteç olan serumdaki C-reaktif protein (CRP) düzeyi ile ilişkisini araştırmaktır.

*Correspondence: ecemkaya@ankara.edu.tr, Phone: +90 31220330 54, ORCID-ID: orcid.org/0000-0002-8490-6293

Received: 21.01.2021, Accepted: 18.04.2021

๑Turk J Pharm Sci, Published by Galenos Publishing House. 
Gereç ve Yöntemler: Bu çalışmada endometriozis ( $n=16)$ ve kontrol grupları ( $n=14)$ ultrason aracılığı ile belirlenmiştir. Serum omentin, vaspin ve irisin seviyeleri ELISA yöntemi ile ölçülmüștür. Serumda CRP seviyeleri ile tam kan örneklerinde visfatin ve vaspin gen ekspresyonu sırası ile klinik analiz cihazı ve gerçek zamanlı-polimeraz zincir reaksiyonu ile belirlenmiştir.

Bulgular: Endometriozis grubunda, serum irisin ve CRP seviyeleri kontrol grubuna göre anlamlı olarak yüksek bulunmuştur. Endometriozis tanısı alan kadınlarda irisin protein düzeyleri, vücut kitle indeksi ve CRP ile pozitif korelasyon göstermiștir. Serum omentin ve vaspin düzeylerinde gruplar arasında istatistiksel olarak anlamlı fark bulunmamıștır. Endometriozis grubundan alınan tam kan örneklerinde, visfatin ve vaspin gen ekspresyonu, kontrol grubuna göre anlamlı derecede düşük bulunmuştur.

Sonuç: Serum irisin düzeylerinde artma ve kanda visfatin ve vaspin gen ekspresyonunda azalma endometrioziste potansiyel bir biyobelirteç olarak düşünülebilir. Endometriozis varlığında değişiklik gösteren yeni adipositokinlerin ve bu adipositokinler ile inflamasyon arasındaki ilișkinin tanımlanması, endometrioziste rol oynayan mekanizmaların tespitini kolaylaştıracak ve hedeflendirilmiş tedavinin geliştirilmesine yol açacaktır.

Anahtar kelimeler: Endometriozis, adipositokinler, inflamasyon

\section{INTRODUCTION}

Endometriosis is a painful disorder identified by the growth of endometrium-like tissue such as endometrial glands and stroma, outside the uterus.' Endometriosis reduces the quality of life among women due to dysmenorrhea, chronic pelvic pain, irregular uterine bleeding, infertility and affects about $5 \%-10 \%$ of women of reproductive age. ${ }^{2,3}$ Previous studies have reported that $30 \%-40 \%$ of infertile women have endometriosis, and they are more likely to have endometriosis than fertile women. ${ }^{4,5}$

A standardized approach for the definite diagnosis of endometriosis is laparoscopic visualization of lesions together with histological examination. ${ }^{2}$ Besides, transvaginal ultrasound is an alternative technique to diagnose pelvic endometriosis. ${ }^{6}$ The current gold standard for the definitive treatment of endometriosis involves surgical removal of ectopic lesions and/ or hormonal suppression.' The identification of mechanisms in the pathogenesis of endometriosis remains critical for reducing various side effects of these treatment options and a high incidence of relapses. ${ }^{?}$

Chronic inflammation plays a considerable role in the development and progression of endometriosis in the peritoneal cavity. ${ }^{8}$ Adipocytokines are proteins secreted from white adipose tissue and affect metabolism, immunity, endocrine system and inflammation regulation and play different and even opposing roles. ${ }^{910}$ Accumulating evidence suggests that pro- or anti-inflammatory actions of adipocytokines and inflammatory markers are partly responsible for the pathogenesis of endometriosis. ${ }^{11,12}$

Omentin-1 is a circulating novel hydrophilic adipokine with extensive protective effects in various diseases. ${ }^{13}$ Vaspin known as visceral adipose tissue-derived serine protease inhibitor, is a member of the serine protease inhibitor family and was first identified as an adipokine that is expressed mainly in the visceral adipose tissue of Zucker fatty rats..$^{14}$ Irisin has been identified as a novel myokine which is involved in white adipose tissue browning and anti-inflammatory pathways. ${ }^{15} \mathrm{~A}$ ubiquitous intracellular enzyme, visfatin is known also as nicotinamide phosphoribosyltransferase and pre-B-cell colony-enhancing factor. ${ }^{16}$

This study was conducted to investigate a possible role of "omentin, vaspin, irisin and visfatin" adipocytokines called "new adipocytokines" and their association with the inflammatory marker C-reactive protein (CRP) levels in endometriosis.

\section{MATERIALS AND METHODS}

\section{Study subjects}

Thirty women attending Dr. Zekai Tahir Burak Women's Health Care Education and Research Hospital were enrolled in this study. The women were divided into two groups as control $(n=14)$ and endometriosis $(n=16)$ via ultrasound examination. Blood samples of all participants were collected and divided into test tubes containing K3EDTA and serum-separating tubes after overnight fasting to perform biochemical analysis. Serum was obtained by centrifugation at $400 \times \mathrm{g}$ for $10 \mathrm{~min}$ and both whole blood and serum samples were stored at $-70^{\circ} \mathrm{C}$ until further analysis. This study was conducted with the approval of Ankara University Faculty of Medicine Clinical Research Ethics Committee (19-1296-18) and standard informed consent was obtained from women involved in this study.

Measurement of adipocytokines (omentin, vaspin, irisin) and inflammatory marker (CRP) concentrations in serum

The circulating levels of omentin in the serum were assayed using commercially available ELISA kits (catalog no. E-EL-H2028, Elabscience, Houston, Texas, United States). Serum vaspin and irisin concentrations in the serum were detected by a commercially available ELISA kit [catalog no. CSB-E09771h (vaspin) and CSB-EQ027943HU (irisin), Cusabio Biotechnology, Wuhan, China]. The minimum detectable concentration of omentin, vaspin, and irisin was $0.38 \mathrm{ng} / \mathrm{mL}, 7.8$ $\mathrm{pg} / \mathrm{mL}$, and $0.78 \mathrm{ng} / \mathrm{mL}$, respectively. For the omentin ELISA, the intra-assay coefficient of variation (CV) was $<4.05 \%$; the inter-assay $\mathrm{CV}$ was $\langle 3.12 \%$. For the vaspin and irisin ELISA kits, the intra-assay $\mathrm{CV}$ was $\langle 8 \%$; the inter-assay $\mathrm{CV}$ was $\langle 10 \%$. A biomarker of inflammation, CRP levels were measured by Beckman Coulter AU680 clinical chemistry analyzer (Beckman Coulter Inc., Brea CA, USA).

\section{RNA isolation and complementary DNA (cDNA) synthesis}

Total RNA was isolated from whole blood samples using the RNA isolation kit (Macherey-Nagel, Düren, Germany) according to the manufacturer's instructions. The concentration of each total RNA was determined by spectrophotometer (NanoDrop ND-1000 spectrophotometer; Thermo Scientific, Wilmington, DE, USA). Equal amounts of total RNA (200 $\mathrm{ng}$ ) from each sample were used for the production of complementary DNA (cDNA) using the ProtoScript II first strand cDNA synthesis 
kit (New England Biolabs, Ipswich, MA,USA) according to the manufacturer's protocol.

Each transcription was performed in a reaction buffer containing $200 \mathrm{ng}$ of total RNA ( $2 \mu \mathrm{L}$ for each sample), $50 \mu \mathrm{M} \mathrm{d}(\mathrm{T})_{23} \mathrm{VN}$ $(2 \mu \mathrm{L}), 10 \mu \mathrm{L}$ reaction mix (dNTPs and optimized buffer), $2 \mu \mathrm{L}$ enzyme mix (reverse transcriptase and RNase inhibitor) and 4 $\mu \mathrm{L}$ RNase-free water for a total volume of $20 \mu \mathrm{L}$. After brief centrifugation, the reaction mixture was incubated at $42^{\circ} \mathrm{C}$ for $10 \mathrm{~min}$, and then heated at $80^{\circ} \mathrm{C}$ for $5 \mathrm{~min}$.

\section{Quantitative real-time polymerase chain reaction (RT-PCR) assay}

For the analysis of mRNA level of visfatin and vaspin, the newly synthesized cDNA was quantified on RT-PCR using CFX384 touch RT-PCR System (Bio-rad, Hercules, CA, USA) and Luna Universal qPCR Master Mix (New England Biolabs, Ipswich, MA, USA) according to the manufacturer's protocol. Each qRT-PCR reaction was carried out in $20 \mu \mathrm{L}$ buffer, containing the same volume of the newly synthesized cDNA $(2 \mu \mathrm{L})$ from each sample, $10 \mu \mathrm{L}$ master mix, $1 \mu \mathrm{L}$ forward and reverse primer $(0,25 \mu \mathrm{M})$, and $7 \mu \mathrm{L}$ DNA-free water. The oligonucleotide sequences of the primer pairs which were designed using the ensemble genome browser and primer 3 input programs are summarized in Table 1. The thermocycling protocol was performed as follows in duplicate: Initial denaturation at $95^{\circ} \mathrm{C}$ for $1 \mathrm{~min}$, followed by 40 cycles of PCR at $95^{\circ} \mathrm{C}$ for $15 \mathrm{~s}$ and $60^{\circ} \mathrm{C}$ for $30 \mathrm{~s}$. After 40 cycles, a melting step was performed at $60^{\circ} \mathrm{C}$ for $15 \mathrm{~s}$. The relative mRNA expression was quantified by comparison with $\beta$-actin as a housekeeping gene from the same sample as an internal control. The relative gene expressions of visfatin and vaspin were computed using the $2^{-\triangle \Delta C T}$ as fold changes relative to those in controls. ${ }^{17}$ At the end of the RT-PCR, product specificity was verified using a melting curve.

\section{Statistical analyses}

The statistical analyses were conducted using the SPSS software version 18.0. Mean values between the groups were compared by Student's t-test. Pearson's correlation coefficient was used to identify the relationship between parameters. A $p<0.05$ was considered statistically significant.

\section{RESULTS}

A total of 30 women between the ages of $25-40$ years old

\section{Table 1. Sequences of primers used in RT-PCR}

\begin{tabular}{ll} 
Gene & Primer sequences $\left(5^{\prime}-3^{\prime}\right)$ \\
\hline \multirow{2}{*}{ Vaspin } & Forward: TACTGGGGATGTGGGGAGAG \\
\hline \multirow{3}{*}{ Visfatin } & Reverse: TGTAGGGCCGATGAGTCAGA \\
\hline \multirow{3}{*}{$\beta$-actin } & Forward: TCGGTTCTGGTGGAGGTTTG \\
\hline & Rerward: ACCTGCATTTCCTGGGAGTG \\
\hline
\end{tabular}

RT-PCR: Real-time polymerase chain reaction participated in this study, including sixteen diagnosed with endometriosis and fourteen healthy women. Among the patients in the endometriosis group, the presence of dysmenorrhea was documented in 10 (35.8\%) patients, while rest of 6 (64.2\%) patients with endometriosis did not have dysmenorrhea.

There were no statistically significant differences in the serum omentin and vaspin concentrations between control and endometriosis groups ( $p$ values $0.861 ; 0.213$, respectively; Figure 1). However, serum irisin levels were statistically higher in the endometriosis group than in the control group $(p=0.024$, Figure 2A) and significantly positively correlated with both body mass index (BMI) $(r=0.65, p=0.021)$ and CRP levels ( $r=0.714, p=0.023$ ) in women with endometriosis (Table 2). Serum CRP level was significantly increased in women with endometriosis compared to the control group ( $p=0.022$, Figure 2B). Additionally, we measured the gene expression of vaspin and visfatin in whole blood samples of women with and without
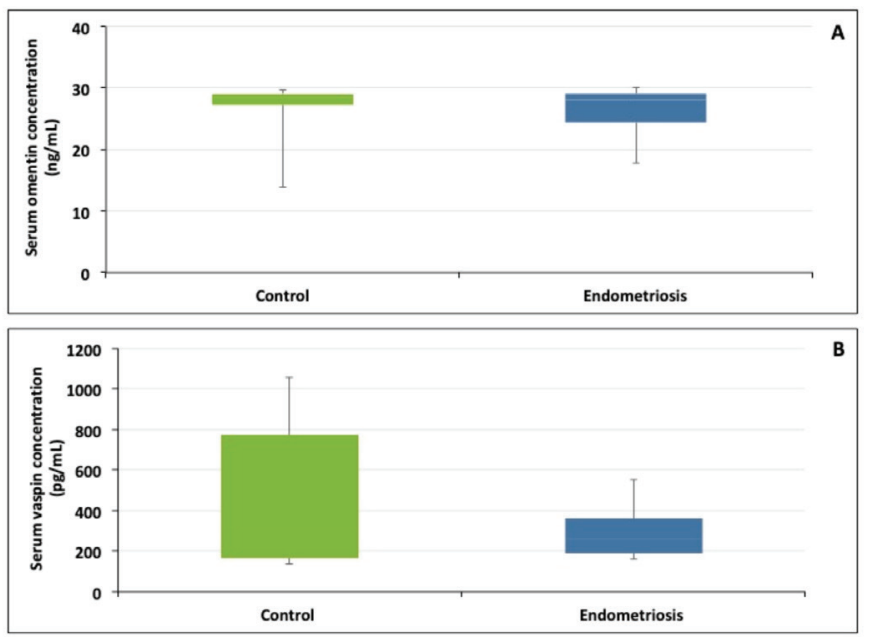

Figure 1. (A) Omentin and (B) vaspin concentration in serum from controls $(n=14)$ and patients with endometriosis $(n=16)$. Data are expressed as the median and range
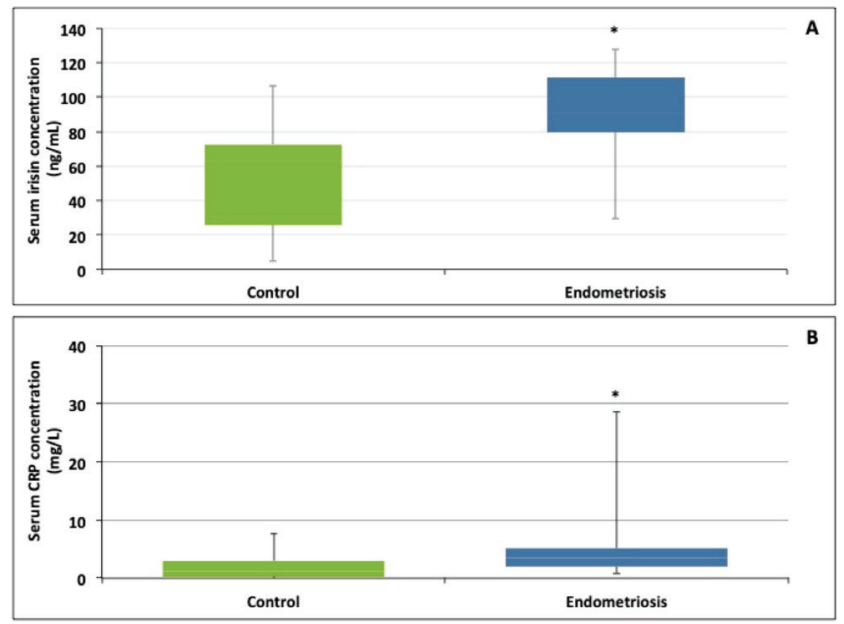

Figure 2. (A) Irisin and (B) CRP concentration in serum from controls $(n=14)$ and patients with endometriosis $(n=16)$. Data are expressed as the median and range

${ }^{*} p<0.05$ compared to controls. CRP: C-reactive protein 
endometriosis. Our results revealed that the mRNA expression levels of vaspin and visfatin in whole blood from endometriosis patients were significantly lower than the control group ( $p$ values $0.042 ; p=0.00097$, respectively; Figure 3 ). While no significant association between the levels of vaspin, visfatin and clinical parameters was found in the endometriosis, the visfatin mRNA expression tended to positively correlate with $\mathrm{BMI}$ in patients with endometriosis, though without statistical significance ( $r=0.5, p=0.059$, Table 2$)$.

\section{DISCUSSION}

In this study, we firstly demonstrated that serum irisin and CRP concentrations were significantly higher in women with endometriosis than those without the disease. A significant positive correlation between serum irisin levels and both BMI and CRP levels was observed. In particular, decreased visfatin and vaspin gene expressions in whole blood samples were remarkable for women with endometriosis compared to healthy controls. There was a trend toward a positive correlation between BMI and visfatin mRNA expression, which was statistically non-significant.

Based on our results, serum omentin and vaspin concentrations did not differ between endometriosis and control groups and were not correlated with any parameter. However, vaspin mRNA expression levels were decreased in patients with endometriosis compared to healthy controls. Omentin and vaspin are anti-
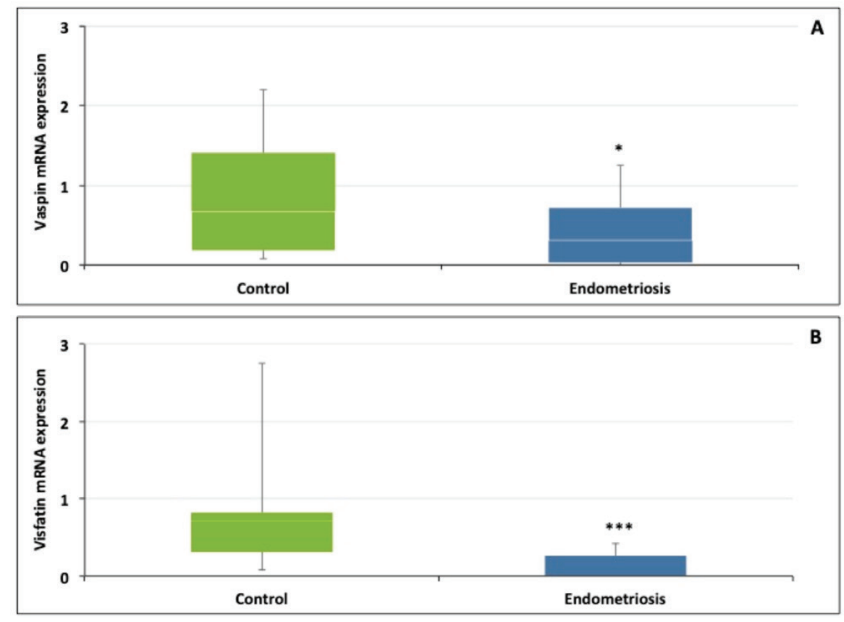

Figure 3. (A) Vaspin and (B) visfatin mRNA expression in whole blood from controls $(n=14)$ and patients with endometriosis $(n=16)$. Data are expressed as the median and range

${ }^{*} p<0.05,{ }^{* \star} p<0.001$ compared to controls inflammatory mediators, ${ }^{18-21}$ and decreased expression of these adipocytokines was detected in various chronic inflammatory diseases. ${ }^{22,23}$ In this study, a non-significant partial decrease in vaspin protein level with significantly decreased vaspin mRNA expression may be related to the small number of subjects and severity of endometriosis in patients. In accordance with the growing evidence suggesting anti-inflammatory effects of vaspin, ${ }^{14}$ endometriosis occurrence may be associated with decreased vaspin mRNA levels and vaspin could serve as a novel biomarker of endometriosis.

This study showed that circulating irisin levels were increased in patients with endometriosis compared to control subjects and were correlated with BMI and CRP. Some authors support our findings with reports of higher irisin levels in women with gestational diabetes and polycystic ovary syndrome. 24,25 These findings are in contrast to other studies, which indicated lower serum irisin levels compared to control in inflammationrelated diseases. ${ }^{15,26,27}$ Similarly, there was a significant positive correlation between serum irisin concentrations and $\mathrm{BMI}, 25,28,29$ although other studies suggested an inverse association between irisin levels and BMI. 15,30 Previous preclinical and clinical studies suggested that irisin has anti-inflammatory properties, reducing secretion of inflammatory cytokines like interleukin-6 and tumor necrosis factor- $\alpha$. $^{31,32}$ It is well established that increased levels of various proinflammatory cytokines play an important role in the pathogenesis of endometriosis. ${ }^{33}$ The current results led us to speculate that increased circulating irisin may be an adaptive response to compensate for increased inflammation in endometriosis, which was also supported by a positive association between irisin and CRP and its anti-inflammatory properties. We can suggest an "irisin-proinflammatory/antiinflammatory axis" to elucidate the role of irisin as a possible indicator in endometriosis.

CRP levels were increased in women with endometriosis in this study. Results reporting CRP levels in peripheral blood of endometriosis patients compared to controls are relatively contradictory due to differences in the severity of endometriosis, different measurement techniques, the sample size of studies. ${ }^{34-36}$ We suggest that CRP could reveal subclinical inflammation in serum of women with endometriosis and serve as a biomarker of endometriosis which is considered a chronic inflammatory disease as reported previously. ${ }^{37,38}$

Visfatin is considered a new marker of inflammation, which is in line with reports suggesting that visfatin induces nuclear factor kappa B activity and the synthesis of other related proinflammatory molecules. ${ }^{16,39,40}$ Since higher relative visfatin

Table 2. Correlations between BMI, CRP and adipocytokines in patients with endometriosis

\begin{tabular}{|c|c|c|c|c|c|c|c|c|c|c|}
\hline \multicolumn{3}{|c|}{ Serum omentin concentration $(\mathrm{ng} / \mathrm{mL})$} & \multicolumn{2}{|c|}{$\begin{array}{l}\text { Serum vaspin } \\
\text { concentration }(\mathrm{pg} / \mathrm{mL})\end{array}$} & \multicolumn{2}{|c|}{$\begin{array}{l}\text { Serum irisin } \\
\text { concentration }(\mathrm{ng} / \mathrm{mL})\end{array}$} & \multicolumn{2}{|c|}{$\begin{array}{l}\text { Vaspin gene } \\
\text { expression }\end{array}$} & \multicolumn{2}{|c|}{$\begin{array}{l}\text { Visfatin gene } \\
\text { expression }\end{array}$} \\
\hline & $r$ & $\mathrm{p}$ & $r$ & $\mathrm{p}$ & $r$ & $\mathrm{p}$ & $r$ & $\mathrm{p}$ & $r$ & $\mathrm{p}$ \\
\hline CRP & 0.175 & 0.266 & 0.005 & 0.495 & 0.714 & $0.023^{*}$ & -0.546 & 0.081 & 0.079 & 0.427 \\
\hline
\end{tabular}

${ }^{*} p<0.05$ demonstrates the significance of the correlation, BMI: Body mass index, CRP: C-reactive protein 
mRNA levels in peripheral mononuclear cells from patients with a common inflammatory disease such as polycystic ovary syndrome and diabetes have been reported, 41,42 we suggested that visfatin contributes to endometriosis. Our findings demonstrated that visfatin mRNA expression in whole blood from the women with endometriosis was significantly lower than in the controls and tended to positively associate with the BMI, but not statistically significant. Similarly, a study by Seow et al. ${ }^{42}$ found a non-significant correlation between visfatin and $\mathrm{BMI}$ in patients with polycystic ovary syndrome, which might be attributed to an insufficient sample size that might negatively affect the statistical power. Visfatin with its inflammatory properties might be involved in the pathogenesis of endometriosis. New insight into the role of visfatin may be attractive for novel therapeutic strategies targeting endometriosis-related chronic inflammation.

Moreover, there is no adipocytokine known as non-invasive biomarkers of endometriosis. Further studies with larger population will be required to determine whether these novel adipocytokines are involved in a particular developmental stage of the endometriosis and to clarify the mechanism of action of these inflammatory/anti-inflammatory adipocytokines under endometriotic conditions. The imbalance between pro- and antiinflammatory adipocytokines may be an important causative factor in the pathogenesis of endometriosis.

\section{CONCLUSION}

Our study revealed, for the first time, decreased visfatin and vaspin gene expressions together with increased serum irisin and CRP levels were observed in endometriosis patients compared to control subjects. Our findings suggest that these adipocytokines may play a potential role in the development of endometriosis. Although this study has provided helpful information, many unknown aspects regarding the mechanisms and markers of endometriosis warrant further investigation. Finally, all the data suggest that additional studies are needed to define the significance of novel adipocytokines as prognostic markers and therapeutic targets in the etiology of endometriosis.

\section{ACKNOWLEDGMENTS}

This study was supported by Ankara University Scientific Research Project (19H0237003).

Conflict of interest: No conflict of interest was declared by the authors. The authors are solely responsible for the content and writing of this paper.

\section{REFERENCES}

1. Yoo JY, Kim TH, Fazleabas AT, Palomino WA, Ahn SH, Tayade C, Schammel DP, Young SL, Jeong JW, Lessey BA. KRAS activation and over-expression of SIRT1/BCL6 contributes to the pathogenesis of endometriosis and progesterone resistance. Sci Rep. 2017;7:6765.

2. Zondervan KT, Becker CM, Koga K, Missmer SA, Taylor RN, Viganò P. Endometriosis. Nat Rev Dis Primers. 2018:4:9.
3. Ozkan S, Murk W, Arici A. Endometriosis and infertility: epidemiology and evidence-based treatments. Ann NY Acad Sci. 2008;1127:92-100.

4. Kennedy S, Bergqvist A, Chapron C, D'Hooghe T, Dunselman G, Greb R, Hummelshoj L, Prentice A, Saridogan E; ESHRE Special Interest Group for Endometriosis and Endometrium Guideline Development Group. ESHRE guideline for the diagnosis and treatment of endometriosis. Hum Reprod. 2005;20:2698-2704.

5. Opøien HK, Fedorcsak P, Omland AK, Abyholm T, Bjercke S, Ertzeid G, Oldereid N, Mellembakken JR, Tanbo T. In vitro fertilization is a successful treatment in endometriosis-associated infertility. Fertil Steril. 2012;97:912-918.

6. Fraser MA, Agarwal S, Chen I, Singh SS. Routine vs. expertguided transvaginal ultrasound in the diagnosis of endometriosis: a retrospective review. Abdom Imaging. 2015;40:587-594.

7. Bulun SE. Endometriosis. N Engl J Med. 2009;360:268-279.

8. Oh YK, Ha YR, Yi KW, Park HT, Shin JH, Kim T, Hur JY. Increased expression of resistin in ectopic endometrial tissue of women with endometriosis. Am J Reprod Immunol. 2017;78.

9. Juge-Aubry CE, Henrichot E, Meier CA. Adipose tissue: a regulator of inflammation. Best Pract Res Clin Endocrinol Metab. 2005;19:547-566.

10. Maijer KI, Neumann E, Müller-Ladner U, Drop DA, Ramwadhdoebe TH, Choi IY, Gerlag DM, de Hair MJ, Tak PP. Serum vaspin levels are associated with the development of clinically manifest arthritis in autoantibody-positive individuals. PLoS One. 2015;10:e0144932.

11. Choi YS, Oh HK, Choi JH. Expression of adiponectin, leptin, and their receptors in ovarian endometrioma. Fertil Steril. 2013;100:135-41.e1-2.

12. Jin $\mathrm{CH}, \mathrm{Yi} \mathrm{KW}, \mathrm{Ha}$ YR, Shin JH, Park HT, Kim T, Hur JY. Chemerin expression in the peritoneal fluid, serum, and ovarian endometrioma of women with endometriosis. Am J Reprod Immunol. 2015;74:379-386.

13. Yang RZ, Lee MJ, Hu H, Pray J, Wu HB, Hansen BC, Shuldiner AR, Fried SK, McLenithan JC, Gong DW. Identification of omentin as a novel depotspecific adipokine in human adipose tissue: possible role in modulating insulin action. Am J Physiol Endocrinol Metab. 2006;290:E1253-E1261.

14. Hida K, Wada J, Eguchi J, Zhang H, Baba M, Seida A, Hashimoto I, Okada T, Yasuhara A, Nakatsuka A, Shikata K, Hourai S, Futami J, Watanabe E, Matsuki Y, Hiramatsu R, Akagi S, Makino H, Kanwar YS. Visceral adipose tissue-derived serine protease inhibitor: a unique insulin-sensitizing adipocytokine in obesity. Proc Natl Acad Sci USA. 2005;102:10610-10615.

15. Huerta-Delgado AS, Roffe-Vazquez DN, Gonzalez-Gil AM, VillarrealCalderón JR, Tamez-Rivera O, Rodriguez-Gutierrez NA, Castillo EC, Silva-Platas C, Garcia-Rivas G, Elizondo-Montemayor L. Serum irisin levels, endothelial dysfunction, and inflammation in pediatric patients with type 2 diabetes mellitus and metabolic syndrome. J Diabetes Res. 2020;2020:1949415

16. Kang YS, Song HK, Lee MH, Ko GJ, Cha DR. Plasma concentration of visfatin is a new surrogate marker of systemic inflammation in type 2 diabetic patients. Diabetes Res Clin Pract. 2010;89:141-149.

17. Livak KJ, Schmittgen TD. Analysis of relative gene expression data using real-time quantitative PCR and the 2(-Delta Delta $C(T)$ ) method. Methods. 2001;25:402-408

18. Yamawaki H, Kuramoto J, Kameshima S, Usui T, Okada M, Hara Y. Omentin, a novel adipocytokine inhibits TNF-induced vascular inflammation in human endothelial cells. Biochem Biophys Res Commun. 2011:408:339-343. 
19. Zhong X, Li X, Liu F, Tan H, Shang D. Omentin inhibits TNF- $\alpha$-induced expression of adhesion molecules in endothelial cells via ERK/NF- $\mathrm{KB}$ pathway. Biochem Biophys Res Commun. 2012;425:401-406.

20. Li H, Peng W, Zhuang J, Lu Y, Jian W, Wei Y, Li W, Xu Y. Vaspin attenuates high glucose-induced vascular smooth muscle cells proliferation and chemokinesis by inhibiting the MAPK, PI3K/Akt, and NF-KB signaling pathways. Atherosclerosis. 2013;228:61-68.

21. Phalitakul S, Okada M, Hara Y, Yamawaki H. Vaspin prevents TNF- $\alpha-$ induced intracellular adhesion molecule-1 via inhibiting reactive oxygen

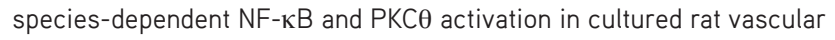
smooth muscle cells. Pharmacol Res. 2011;64:493-500.

22. Watanabe T, Watanabe-Kominato K, Takahashi Y, Kojima M, Watanabe R. Adipose tissue-derived omentin-1 function and regulation. Compr Physiol. 2017;7:765-781.

23. Li HL, Peng WH, Cui ST, Lei H, Wei YD, Li WM, Xu YW. Vaspin plasma concentrations and mRNA expressions in patients with stable and unstable angina pectoris. Clin Chem Lab Med. 2011;49:1547-1554.

24. Ebert T, Stepan H, Schrey S, Kralisch S, Hindricks J, Hopf L, Platz M, Lossner U, Jessnitzer B, Drewlo S, Blüher M, Stumvoll M, Fasshauer M. Serum levels of irisin in gestational diabetes mellitus during pregnancy and after delivery. Cytokine. 2014;65:153-158.

25. Li M, Yang M, Zhou X, Fang X, Hu W, Zhu W, Wang C, Liu D, Li S, Liu $H$, Yang G, Li L. Elevated circulating levels of irisin and the effect of metformin treatment in women with polycystic ovary syndrome. J Clin Endocrinol Metab. 2015;100:1485-1493.

26. Gamal RM, Mohamed ME, Hammam N, El Fetoh NA, Rashed AM, Furst DE. Preliminary study of the association of serum irisin levels with poor sleep quality in rheumatoid arthritis patients. Sleep Med. 2020;67:71-76.

27. Ali EY, Hegazy GA, Hashem EM. Evaluation of irisin, retinol-binding protein 4, and leptin serum levels as biomarkers of macrovascular complications involvement in Saudi type 2 diabetes mellitus. A casecontrol study. Saudi Med J. 2020;41:1369-1374.

28. Zhang R, Fu T, Zhao X, Qiu Y, Hu X, Shi H, Yin X. Association of circulating irisin levels with adiposity and glucose metabolic profiles in a middle-aged chinese population: a cross-sectional study. Diabetes Metab Syndr Obes. 2020;13:4105-4112.

29. Stengel A, Hofmann T, Goebel-Stengel M, Elbelt U, Kobelt $P$, Klapp BF. Circulating levels of irisin in patients with anorexia nervosa and different stages of obesity--correlation with body mass index. Peptides. 2013;39:125-130.

30. Huang W, Liu Y, Xu H, Zhu H, Guan J, Yi H, Zou J. Association of the serum irisin level with obstructive sleep apnea: a body mass index- and physical activity-matched study. Endocr J. 2020;67:607-612.
31. Mazur-Bialy Al, Bilski J, Pochec E, Brzozowski T. New insight into the direct anti-inflammatory activity of a myokine irisin against proinflammatory activation of adipocytes. Implication for exercise in obesity. J Physiol Pharmacol. 2017;68:243-251.

32. Park MJ, Kim DI, Choi JH, Heo YR, Park SH. New role of irisin in hepatocytes: the protective effect of hepatic steatosis in vitro. Cell Signal. 2015;27:1831-1839.

33. Wu MY, Ho HN. The role of cytokines in endometriosis. Am J Reprod Immunol. 2003;49:285-296.

34. Xavier P, Belo L, Beires J, Rebelo I, Martinez-de-Oliveira J, Lunet N, Barros $\mathrm{H}$. Serum levels of VEGF and TNF-alpha and their association with $\mathrm{C}$-reactive protein in patients with endometriosis. Arch Gynecol Obstet. 2006;273:227-231.

35. Lermann J, Mueller A, Körber F, Oppelt P, Beckmann MW, Dittrich $\mathrm{R}$, Renner SP. Evaluation of high-sensitivity $\mathrm{C}$-reactive protein in comparison with $\mathrm{C}$-reactive protein as biochemical serum markers in women with endometriosis. Fertil Steril. 2010;93:2125-2129.

36. Mihalyi A, Gevaert O, Kyama CM, Simsa P, Pochet N, de Smet F, de Moor B, Meuleman C, Billen J, Blanckaert N, Vodolazkaia A, Fulop V, D'Hooghe TM. Non-invasive diagnosis of endometriosis based on a combined analysis of six plasma biomarkers. Hum Reprod. 2010;25:654-664.

37. Vodolazkaia A, Bossuyt X, Fassbender A, Kyama CM, Meuleman C, Peeraer K, Tomassetti C, D'Hooghe TM. A high sensitivity assay is more accurate than a classical assay for the measurement of plasma CRP levels in endometriosis. Reprod Biol Endocrinol. 2011;9:113.

38. Fassbender A, Burney RO, O DF, D'Hooghe T, Giudice L. Update on biomarkers for the detection of endometriosis. Biomed Res Int. 2015;2015:130854.

39. Brentano F, Schorr O, Ospelt C, Stanczyk J, Gay RE, Gay S, Kyburz D. Pre-B cell colony-enhancing factor/visfatin, a new marker of inflammation in rheumatoid arthritis with proinflammatory and matrixdegrading activities. Arthritis Rheum. 2007;56:2829-2839.

40. Adya R, Tan BK, Chen J, Randeva HS. Nuclear factor-kappaB induction by visfatin in human vascular endothelial cells: its role in MMP-2/9 production and activation. Diabetes Care. 2008;31:758-760.

41. Tsiotra PC, Tsigos C, Yfanti E, Anastasiou E, Vikentiou M, Psarra K, Papasteriades C, Raptis SA. Visfatin, TNF-alpha and IL-6 mRNA expression is increased in mononuclear cells from type 2 diabetic women. Horm Metab Res. 2007;39:758-763.

42. Seow KM, Hwang JL, Wang PH, Ho LT, Juan CC. Expression of visfatin mRNA in peripheral blood mononuclear cells is not correlated with visfatin mRNA in omental adipose tissue in women with polycystic ovary syndrome. Hum Reprod. 2011;26:2869-2873. 